\title{
TELAAH SOSIOLOGIS PENYEBAB PELANGGARAN PENGUASAAN TANAH DI LINGKUNGAN PESISIR DI KABUPATEN LAMPUNG SELATAN
}

\author{
Yuwono Prianto ${ }^{1}$, Benny Djaja ${ }^{2}$, Mella Ismelina F.R. ${ }^{3}$, dan Indah Siti Aprilia ${ }^{4}$ \\ ${ }^{1}$ Fakultas Hukum, Universitas Tarumanagara,Jakarta \\ Email: yuwonop@fh.untar.ac.id \\ ${ }^{2}$ Fakultas Hukum, Universitas Tarumanagara, Jakarta \\ Email: mbennydjaja.bd@gmail.com \\ ${ }^{3}$ Fakultas Hukum, Universitas Tarumanagara, Jakarta \\ Email: mellaismelina@fh.untar.ac.id \\ ${ }^{4}$ Mahasiswa Magister Hukum, Universitas Indonesia, Jakarta \\ Email: indahsitiaprilia@gmail.com
}

\begin{abstract}
Cultivation in coastal area usually did for business activity purpose against the villagers without giving concern for the nature \& ecosystem impact. Coastal area have high level of potential conflict either marine aspect nor land authorization. Misuse \& violation against coastal area indicate by construction frequently founded along shoreline. Restricted ban against shoreline is a prohibition that require villagers to not build a construction long 100 meters from shoreline. The law against shoreline intend to protect the villagers from tsunami and environmental damage thru human behavior. South Lampung District have high potential level of tsunami by reason the location is close to Krakatau Mountain. In advance of Tsunami 2018 which rushed Banten \& South Lampung District throw a big disadvantage and had public nor government attention. In fact, there are a lot of construction who violate shoreline regulation. This research using empiric method which elaborate with direct observation. Faced by the low government supervision reveal the low level of villagers legal awareness about obligations and social function of the land as well as urgency of the preservation of environmental functions on the coast.
\end{abstract}

Keywords: Offense, land tenure, environmental function

\begin{abstract}
ABSTRAK
Masyarakat wilayah pesisir kerap menggunakan pesisir untuk melakukan kegiatan usaha tanpa memikirkan dampak terhadap lingkungan \& ekosistem. Wilayah pesisir rentan menjadi sumber konflik baik dari segi kelautan maupun penguasaan atas tanah wilayah pesisir. Penyalahgunaan \& pelanggaran terhadap wilayah pesisir ditandai dengan kerap ditemukan bangunan yang berdiri di sepanjang pesisir yang melanggar ketentuan Garis Sempadan Pantai (GSP). Larangan mendirikan bangunan di sepanjang garis sempadan pantai adalah larangan terhadap masyarakat untuk tidak mendirikan bangunan di sepanjang 100 meter dari garis pantai. Peraturan mengenai Garis Sempadan Pantai sejatinya bertujuan untuk melindungi masyarakat dari bahaya tsunami dan kerusakan lingkungan yang ditimbulkan oleh ulah manusia. Wilayah Kabupaten Lampung Selatan merupakan wilayah yang rentan akan bahaya tsunami dikarenakan lokasinya yang berdekatan dengan Gunung Krakatau. Pada Tsunami 2018 silam, wilayah Kabupaten Lampung Selatan merupakan salah satu wilayah yang terdampak bencana Tsunami Selat Sunda. Diketahui banyak ditemukan bangunan yang rusak akibat peristiwa Tsunami 2018 silam pada wilayah Lampung \& Banten. Kerugian yang ditimbulkan oleh tsunami 2018 silam telah menarik perhatian publik \& pemerintah. Fakta menunjukan bahwa banyaknya bangunan yang berdiri melanggar ketentuan GSP. Penelitian ini menggunakan metode penelitian empiris melakukan pengumpulan data pustaka, observasi dan wawancara. Hasil penelitian terdapat kurangnya pengawasan yang dilakukan oleh pemerintah yang menyebabkan adanya kesadaran hukum yang kurang memadai dari masyarakat wilayah pesisir.
\end{abstract}

Kata Kunci: Pelanggaran, Penguasaan Tanah, Fungsi Lingkungan 


\section{PENDAHULUAN}

Wilayah pantai dan pesisir merupakan sumber daya alam terpenting penunjang kehidupan masyarakat yang tinggal di daerah pesisir karena terdapat banyak kegiatan yang dapat dilakukan dengan memanfaatkan sumber daya alam tersebut. Kawasan sepanjang pantai merupakan kawasan terpenting dalam penguasaan dan penggunaan tanahnya, karena selain untuk dimanfaatkan juga untuk melakukan kegiatan usaha.

Kompleksitas yang terdapat antara sistem alam dan interaksi dalam pengelolaan sumber daya alam memperjelas urgensi merawat sumber daya alam melalui aturan-aturan yang dikeluarkan baik oleh pemerintah pusat maupun daerah. Aturan yang diberlakukan secara ketat berdampak pada kelestarian lingkungan (Sugandi, 2011).

Salah satu pemanfaatan daerah pesisir pantai adalah resort dan penginapan yang banyak diminati oleh wisatawan sejatinya merugikan para wisatawan itu sendiri. Kerugian tersebut terjadi karena kendati mereka memiliki hak untuk menikmati keindahan pantai, akan tetapi dikarenakan penginapan tersebut didirikan di wilayah garis pantai maka mereka pun secara tidak langsung mengganggu ekosistem pantai. Perpres No 51 Tahun 2016 Tentang Garis Sempadan Pantai di dalamnya menjelaskan bahwa sempadan pantai adalah daratan sepanjang tepian pantai yang lebarnya proporsional dengan bentuk dan kondisi fisik pantai minimal $100 \mathrm{~m}$ dari titik pasang tertinggi ke darat (Kalalo, 2016).

Pemanfaatan daerah pesisir pantai ini, sebagai akibat dari pertumbuhan penduduk yang tinggi sehingga membuat menjamurnya bangunan baik permanen maupun semi permanen di sepanjang pesisir pantai Lampung berakibat pada kegiatan penimbunan lahan di area Garis Sempadan Pantai (untuk selanjutnya disebut GSP). Sebagai contoh, di daerah Cungkeng, Pulau Pasaran telah diterbitkan larangan mendirikan bangunan di sepanjang pesisir pantai namun tidak diindahkan oleh masyarakat setempat. Terlihat ratusan bangunan pemukiman penduduk berdiri di GSP dan jumlah terus bertambah yang ditandai dengan adanya beberapa bangunan yang masih baru (ww.lampost.co). Penguasaan tanah di daerah pesisir dengan banyaknya pendirian penginapan kerap kali pembangunan di Kawasan pesisir itu mengabaikan ketentuan yang mengatur mengenai Garis Sempadan Pantai (GSP).

Akan tetapi bila dilihat secara perspektif sosiologis, daerah sepanjang pesisir pantai juga rawan akan bencana. Bencana sering dipahami sebagai apa yang dirasakan oleh masyarakat sekitar mengenai pengalaman emosional terhadap kejadian yang menimpa hidup mereka. Umumnya dalam pengelolaan bencana alam di Indonesia masih bersifat reaktif. Hal ini membuktikan bahwa faktor-faktor yang berhubungan dengan peningkatan kapasitas adaptasi dalam menghadapi bencana merupakan pilihan kebijakan yang wajib diadopsi dan diimplementasikan. Kesiapsiagaan merupakan faktor penting dalam mitigasi bencana. (Rohani Budi Prihatin,2018)

Melihat mitigasi bencana di Indonesia yang belum baik, menjadikan tsunami yang terjadi pada tahun 2018 telihat terjadi begitu dahsyat dengan memporak porandakan banyak bangunan di sepanjang GSP. Hal ini juga diakibatkan oleh dilanggarnya aturan GSP tersebut menimbulkan kerusakan yang sangat serius pada saat terjadi bencana.

Hingga kemudian Pemerintah Lampung dan Banten membuat suatu kebijakan dengan memberlakukan sanksi tegas bagi mereka yang melakukan pelanggaran terhadap ketentuan sempadan pantai. Pelanggaran yang terjadi merupakan bentuk pelanggaran terhadap RTRW Lampung Selatan. Kebijakan tersebut hadir dalam rangka juga turut melestarikan fungsi lingkungan yang sempat terganggu akibat penguasaan lahan sepanjang GSP yang tidak 
semestinya. Sehingga berdasarkan latar belakang yang disampaikan, maka ditemukan permasalahan terkait dengan penegakan hukum atas pelanggaran ketentuan GSP sepanjang pesisir pantai di Kabupaten Lampung Selatan, dan terkait dengan pelanggaran tersebut dengan pengaruhnya terhadap fungsi lingkungan pesisir di sepanjang pantai Kabupaten Lampung Selatan. Oleh karenanya berlandaskan dari permasalahan-permasalahan tersebut, diharapkan dengan penelitian ini mampu mengetahui pengaruh Tsunami Selat Sunda terhadap penegakan hukum dalam pelanggaran ketentuan GSP sepanjang pesisir pantai dan pengaruhnya terhadap Kecamatan Kalianda dan mengetahui pengaruh penegakan hukum atas pelanggaran ketentuan GSP pasca tsunami terhadap fungsi lingkungan pesisir di sepanjang pantai di daerah Lampung Selatan. Dengan terpecahkannya permasalahan dan tujuan tersebut, maka diharapkan penelitian ini memberikan manfaat bagi masyarakat di pesisir pantai Kabupaten Lampung Selatan agar senantiasa menaati aturan pendirian bangunan di sepanjang garis GSP yang nantinya akan bermuara pada terciptanya kelestarian lingkungan hidup di daerah garis pantai tersebut.

\section{METODE PENELITIAN}

Penelitian ini merupakan penelitian empiris sosiologis. Sumber data yang digunakan adalah data primer dan data sekunder. Data primer adalah data dan informasi yang diperoleh secara langsung dari sumber pertama yang terkait dengan permasalahan yang akan dibahas. Data sekunder adalah data dan informasi yang diperoleh dari buku-buku sebagai data pelengkap sumber data primer. Sumber data sekunder penelitian ini adalah data dan informasi yang diperoleh dengan melakukan kajian Pustaka seperti buku-buku ilmiah, hasil penelitian dan sebagainya. Penelitian ini juga menggunakan tiga jenis alat pengumpulan data, yaitu studi kepustakaan, observasi dan wawancara untuk mendapatkan hasil yang semaksimal mungkin. Studi dokumen dilakukan di Perpustakaan Fakultas Hukum Universitas Tarumanagara, dimana dilakukan pemilihan buku-buku yang berkaitan dengan kesadaran hukum, dan penegakan hukum. Selanjutnya setelah melakukan studi dokumen Peneliti melakukan Observasi wilayah yang dilakukan dalam kurun waktu 14 (empat belas) hari, dengan melihat gejala-gejala sosial dan hukum dari masyarakat wilayah pesisir. Adapun Wawancara dilakukan 4 (empat) Kecamatan berbeda yaitu, Kecamatan Rajabasa, Kecamatan Kalianda, Kecamatan Katibung dan Kecamatan Sidomulyo. Peneliti melakukan wawancara dengan tokoh-tokoh masyarakat di 4 (empat) kecamatan tersebut, kemudian dengan Sekretaris Desa Maja, Sekretaris Kecamatan Kalianda, Kepala Desa Pauh Tanjung Iman, Staff Bagian Pajak Bumi dan Bangunan, Camat Rajabasa, Staff Kecamatan Rajabasa, Badan Pemasyarakatan Desa Kunjir, Kepala Desa Tarahan, KAPOLSEK Kalianda, dan terakhir adalah wawancara dengan Kepala BNPB Lampung Selatan.

\section{HASIL DAN PEMBAHASAN}

Pemanfaatan lahan merupakan hal pokok yang selalu melekat pada manusia sepanjang masa hidupnya mulai dari proses kelahiran hingga proses kematian. Peningkatan jumlah penduduk setiap tahunnya membuat lahan semakin sempit dikarenakan tingkat kebutuhan \& pemanfaatan akan lahan semakin tinggi. Peningkatan kebutuhan akan lahan yang semakin tinggi akibat meningkatnya kepadatan penduduk tidak jarang menimbulkan konflik atau penyalahgunaan fungsi lahan (Iswandi Umar, 2017).

Tingkat pertumbuhan penduduk yang tinggi membuat pemanfaatan akan sumber daya alam tidak memperhatikan kemampuan daya dukung lingkungan sehingga terjadi penurunan kualitas lingkungan. Kawasan pesisir merupakan kawasan dengan tingkat mobilitas dan pemanfaatan yang tinggi membuatnya harus selalu siap dalam menghadapi berbagai akibat yang ditimbulkan dari setiap aktivitas yang dilakukan (Hidayah \& Suharyo, 2018). 
Alih fungsi lahan akibat pertumbuhan penduduk tidak dapat dihindarkan. Marak ditemukan bangunan-bangunan di sepanjang bibir pantai harus segera mendapat perhatian yang serius. Penjelasan tersebut juga mengingat bahwa wilayah pesisir identik dengan daerah rawan bencana. Bencana yang kerap timbul di wilayah pesisir adalah Tsunami.

Pengelolaan dan perlindungan akan kawasan pesisir dan pulau-pulau kecil sejatinya diatur melalui Hak Penguasaan Perairan Pesisir (HP3). Dalam sistem pengelolaannya, Kawasan pesisir ternyata tidak dapat dipisahkan dari status fungsi kepemilikan lahan pada Kawasan tersebut. Segala pemberian dan kepemilikan hak atas tanah diatur secara penuh oleh Undang-Undang Pokok Agraria \& peraturan yang berkaitan dengannya. Ketergantungan masyarakat Indonesia akan laut yang begitu tinggi ditandai dengan sebanyak 51,43\% nelayan menggantungkan hidupnya pada kegiatan penangkaran ikan di laut. Dari sektor ekonomi, laut juga memberikan kontribusi yang besar dalam peningkatan ekonomi di Indonesia (Badan Pusat Statistik, 2018).

Berbicara mengenai pelanggaran GPS pada daerah HP3. Sejatinya aspek penegakan hukum di Indonesia sudah mengakomodirnya. Hukum sebagai kaidah yang hidup dalam masyarakat yang bersifat memaksa serta memberikan sanksi terhadap para pelanggarnya. Hukum dalam pembentukannya mengedepankan kepentingan negara dan juga kepentingan umum masyarakat yang terdapat di dalamnya. Hukum merupakan kaidah yang hidup dalam masyarakat yang bersifat memaksa serta memberikan sanksi terhadap para pelanggarnya. Hukum dalam pembentukannya mengedepankan kepentingan negara dan juga kepentingan umum masyarakat yang terdapat di dalamnya (Jainah, 2012). Akan tetapi pelanggaran hukum biasanya terjadi akibat penegakan hukum yang dilakukan oleh aparat adalah lemah maka masyarakat menggambarkan hukum sebagai sesuatu yang tidak ada sehingga enggan untuk tunduk kepada peraturan yang berlaku (Jainah, 2012).

Kebijakan hukum di Indonesia dapat diartikan sebagai kebijakan yang menghasilkan peraturan perundang-undangan dan penerapan hukum akan suatu peraturan perundang-undangan. Asas desentralisasi dan otonomi daerah yang dianut oleh pemerintah Indonesia menjadikan segala urusan yang ada dilimpahkan kepada daerah masing-masing. Pemberlakuan otonomi daerah memungkinkan setiap daerah di Indonesia memiliki kewenangan penuh dalam pengelolaan sempadan pantai (Sanjiwani, 2016).

Termasuk dalam hal ini, kebijakan untuk menanggulangi penguasaan tanah dengan banyak dibangunnya bangunan yang melanggar ketentuan GSP. Berdasarkan hasil penelusuran yang telah dilakukan oleh team di lapangan, diketahui bahwa hampir Sebagian besar masyarakat dan bahkan aparat desa tidak mengetahui ketentuan mengenai garis sempadan pantai (GSP). Mereka menjelaskan bahwa sebagian besar bangunan yang berada di Kawasan garis sempadan pantai Lampung Selatan telah memiliki sertifikat hak milik. Bangunan yang memiliki sertifikat hak milik tersebut merupakan bangunan-bangunan tua yang sudah berdiri sejak lama sebelum diberlakukan peraturan mengenai GSP. Dalam hal ini aparat desa tidak dapat melakukan banyak untuk menindak bangunan yang melanggar GSP. Warga pesisir pantai Lampung Selatan juga tidak mengindahkan konsekuensi akan bahaya akibat banyak dibangunnya bangunan di sepanjang GSP dengan konsekuensi apabila ia mendirikan bangunan yang berdekatan dengan bibir pantai, tetapi mereka memilih untuk tetap tinggal dikarenakan tidak ada ganti rugi yang diberikan. Harga tanah yang cukup mahal dan pendapatan yang tidak maksimal membuat masyarakat terpaksa untuk membeli atau menempati tanah yang berdekatan dengan kawasan GSP untuk tempat tinggal. 
Konsekuensi itu harus dihadapi oleh masyarakat takala terjadi bencana tsunami pada tahun 2018 . Akan tetapi Pasca Tsunami yang menerjang 2018 silam, banyak warga yang memilih untuk tetap tinggal di rumah yang sama walaupun tempat tinggal mereka sudah rata dengan tanah dan berada di dalam kawasan GSP. Pemerintah sudah memberikan sosialisasi dan imbauan kepada mereka untuk mencari lokasi baru untuk tinggal tetapi tidak dipedulikan oleh warga sekitar. Sanksi yang diberikan kepada mereka yang membangun atau mendirikan bangunan di kawasan garis sempadan pantai (GSP) hanya berupa teguran.

Pemerintah daerah setempat memiliki peran serta yang besar untuk terciptanya kesadaran hukum masyarakat Kabupaten Lampung Selatan mengenai ketentuan garis sempadan pantai (GSP). Apabila bangunan telah melanggar ketentuan GSP sebaiknya tidak diberikan izin untuk mendirikan bangunan di lokasi yang sama pasca terjadinya tsunami atau tidak diberikan bantuan kepada mereka yang mendirikan bangunan melanggar ketentuan GSP. Pada penelitian ini ditemukan bahwa aparat kepolisian enggan memberikan sanksi bagi mereka yang melanggar ketentuan GSP karena sebagian besar dari mereka telah menempati lahan tersebut lama sebelum peraturan mengenai GSP diundangkan oleh pemerintah dan pemerintah daerah setempat. Sikap hukum masyarakat pesisir terhadap penguasaan tanah wilayah pesisir masih menganut pola pikir yang sama, namun hal ini dapat berubah, apabila ada perhatian khusus dari pemerintah setempat. Kurangnya sosialisasi mengakibatkan pola pikir dan perilaku masyarakat tetap pada keadaan yang tidak pada standar. Kesadaran hukum berkaitan dengan nilai-nilai yang tumbuh dan berkembang dalam suatu masyarakat yang mana masyarakat menaati hukum bukan karena paksaan, melainkan karena hukum itu sesuai dengan nilai-nilai yang ada dalam masyarakat itu. Kesadaran hukum berkaitan pula dengan efektivitas hukum dan wibawa hukum. Sebagaimana yang telah disinggung secara singkat pada bagian sebelumnya bahwa kemajuan teknologi transportasi yang diiringi dengan perbaikan penambahan infrastruktur membuat banyak orang dari berbagai wilayah melihat bahwa keindahan alam sepanjang pesisir pantai Kabupaten Lampung Selatan memiliki potensi dan membuka peluang untuk orang mencari nafkah dan bertempat tinggal secara menetap di kawasan tersebut. Tekanan penduduk di berbagai kota besar seperti Jakarta dan kota besar lainnya juga keinginan orang dari berbagai daerah yang situasinya tidak berbeda jauh atau bahkan relatif lebih miskin dari taraf hidup masyarakat Kabupaten Lampung Selatan membuat banyak orang melakukan migrasi dari daerah asalnya untuk memperbaiki taraf hidup.

Sejatinya apabila kita melihat dalam Undang Undang Nomor 5 Tahun 1960 tentang Peraturan Dasar Pokok-Pokok Agraria dalam Pasal 6 dinyatakan bahwa "Semua hak atas tanah mempunyai fungsi sosial." Yang mana pasal tersebut selanjutnya dinyatakan sebagai salah satu asas hukum tanah yang diistilahkan asas fungsi sosial hak atas tanah. Keberadaan fungsi sosial tersebut menjadi landasan yang fundamental bagi terwujudnya tanah yang bermanfaat bagi sebesar-besar kemakmuran rakyat di negara kesejahteraan (Rejekiningsih, 2016). Terkait dengan keberadaan asas fungsi sosial hak atas tanah pada negara hukum sebagai salah satu asas hukum agraria, memiliki peran yang sangat penting dalam mewujudkan tujuan negara dalam konsep welfare state seperti Indonesia. Terkandung makna dalam asas fungsi sosial hak atas tanah, adanya pemenuhan hak atas tanah untuk sebesar-besar kemakmuran rakyat sebagaimana ketentuan dalam konstitusi UUD NRI Tahun 1945 (Rejekiningsih, 2016). Oleh karenanya tanah dalam GSP tersebut hendaknya dipergunakan untuk kemakmuran rakyat bersama, terutama rakyat yang bermukim di wilayah sepanjang pantai tersebut, bukan dijadikan komoditi untuk kepentingan pribadi semata. 
Kemudian, meskipun tanah memiliki fungsi sosial, akan tetapi perlu dipahami juga terdapat sebuah pembatasan atas pemilikan dan penguasaan hak atas tanah dalam perspektif reforma agraria. Merujuk pada Pasal 7 UUPA melarang pemilikan dan penguasaan tanah yang melampaui batas. Ketentuan ini bertujuan untuk mencegah dan mengakhiri groot-grondbezit yaitu bertumpuknya kepemilikan tanah di tangan golongan orang-orang tertentu. Apabila tanah sepanjang pantai yang GSP tersebut tetap dikuasai oleh pihak-pihak tertentu saja, tentu selain mengabaikan fungsi sosial tanah juga akan melanggar pembatasan hak tanah. Apabila hal ini tidak diatasi maka akan terjadi kesenjangan dan rasa ketidakadilan bagi masyarakat. Mereka yang memiliki modal besar akan berkuasa sementara masyarakat yang memiliki keterbatasan akan merasa dirugikan. Sementara negara selama ini terkesan lebih pragmatis melakukan pembiaran dengan dalil tidak melanggar ketentuan yang berlaku (Reki, 2018).

Faktor lain yang menjadi penyebab semakin masifnya pelanggaran atas ketentuan garis sempadan pantai di kawasan pesisir Kabupaten Lampung Selatan adalah kurangnya pemahaman aparatur desa, kecamatan hingga kabupaten demikian juga dengan tokoh masyarakat, tokoh pemuda, dan tokoh agama tentang perlunya kepatuhan terhadap ketentuan garis sempadan pantai yang tidak hanya menyangkut soal keindahan, kebersihan, dan keamanan di sekitar kawasan pesisir tetapi juga mencakup keselamatan penduduk yang banyak bermukim di wilayah tersebut. Jika terjadi fenomena alam seperti air pasang, badai, maupun gempa bumi serta letusan gunung api yang dapat memicu terjadinya gelombang tsunami. Oleh karenanya adalah mendesak untuk secara intensif dilakukan sosialisasi dan internalisasi berbagai ketentuan tentang pemanfaatan sumber daya di kawasan pesisir maupun laut terutama bagi aparatur pemerintah mulai dari desa hingga kabupaten demikian juga para tokoh masyarakat, tokoh agama, dan tokoh pemuda yang dalam banyak hal dapat berkontribusi untuk membangun kembali kesadaran hukum warga masyarakat tentang arti penting ketentuan garis sempadan pantai dengan segala latar belakang diberlakukan ketentuan tersebut.

Padahal pelanggaran atas ketentuan garis sempadan pantai perlu diminimalisir mengingat bahwa ketika GSP terus digerus untuk kepentingan-kepentingan pribadi, maka akan sulit untuk dilakukan sebuah upaya pelestarian dan upaya konservasi untuk menjaga kelestarian ekosistem pesisir dan pulau-pulau kecil yang sebetulnya adalah surga sumber daya alam bagi masyarakat itu sendiri. Guna mendukung upaya konservasi dan pelestarian ekosistem pesisir pantai sesuai dengan ketentuan dalam UU No. 27 Tahun 2007 tentang Pengelolaan Wilayah Pesisir dan Pulau-Pulau Kecil, maka perlu adanya suatu penegakan hukum yang baik dan ideal bagi pelanggaranpelanggaran tersebut.

Selanjutnya ketika pada awal tahun 2020 penyisiran pantai juga meliputi Kecamatan Kalianda, yang berdasarkan hasil observasi maupun keterangan tokoh masyarakat dan tokoh pemuda setempat maupun warga masyarakat yg bekerja sebagai nelayan diketahui bahwa sejak terjadinya peristiwa tsunami di akhir tahun 2018 tidak ada perubahan yang signifikan atas perilaku warga masyarakat tentang kebiasaan membuang limbah. Jika pada awal tahun 2019 terlihat warga masyarakat mengalami trauma akibat tsunami maka pada awal tahun 2020 terlihat bahwa warga masyarakat terkesan lupa dengan dahsyatnya amukan gelombang tsunami. Tidak bisa dipungkiri bahwa hidup harus terus berlanjut dan untuk itu setiap orang yang sudah dewasa harus menekuni kembali pekerjaan atau profesi tertentu sebagai sumber mata pencaharian yang mendatangkan penghasilan untuk memenuhi kebutuhan hidup. Namun demikian, sepatutnya tiap orang yang tinggal di pesisir apalagi mereka yang pernah mengalami terjangan gelombang tsunami dapat mengambil hikmah dari bencana tersebut dengan menjalankan usaha dan bertempat tinggal yang lokasinya relatif aman jika sewaktu-waktu terjadi kembali gelombang tsunami maupun terjadi 
gelombang pasang yang setiap waktu tertentu terjadi secara berulang. Aparatur Sipil Negara di tingkat Desa/Kelurahan, Kecamatan dan Kabupaten yang bertugas di bidang ketertiban perlu membangun komitmen menegakkan aturan tentang GSP dengan mengadakan patroli berkala secara terus menerus lakukan pengawasan dan penertiban penguasaan tanah di pesisir yg melanggar aturan GSP dengan menjalin kerjasama dengan aparat kepolisian di tingkat Polsek dan Polres, bahkan berkoordinasi dengan pejabat di tingkat Provinsi dan Polda. Tindakan pencegahan seyogyanya tidak hanya berupa pelaksanaan workshop dalam rangka pembentukan tim mitigasi dan penanganan bencana tsunami. Lebih dari upaya untuk melibatkan segenap unsur masyarakat seperti Remaja Masjid, Karang Taruna, Pramuka, OSIS, Kelompok PKK, hobi dan minat dan sebagainya menjadi penting dan strategis dalam upaya persuasif kepatuhan atas aturan GSP dan langkah preventif berupa internalisasi secara berkesinambungan dalam wujud penanaman kembali pohon mangrove dan terumbu karang sebagai aktivitas wisata alam, sebagai upaya pelestarian fungsi lingkungan pesisir yang pada akhirnya memberi peluang terbukanya lapangan kerja yang lebih luas dengan tetap mengindahkan berbagai aturan hukum terkait, khususnya penguasaan tanah di pesisir, lingkungan hidup maupun penanganan bencana.

\section{KESIMPULAN}

Sikap hukum warga masyarakat Kabupaten Lampung Selatan yang bermukim di kawasan pesisir Kecamatan Kalianda, Rajabasa, dan Katibung yang kurang memahami penguasaan tanah di wilayah pesisir terbentuk akibat pembiaran terhadap pelanggaran atas penguasaan tanah di pesisir. Pembiaran tersebut seperti pembiaran terhadap pembangunan jalan, pendirian rumah dan tempat usaha yang makin mendekati bibir pantai sehingga melanggar ketentuan yang berlaku.

Kurangnya pemahaman tersebut diperparah dengan lemahnya penegakan hukum atas pelanggaran ketentuan GSP tersebut juga terjadi pasca tsunami yang dialami. Kegagalan-kegagalan pemerintah untuk memberikan pemahaman yang komprehensif tersebut telah mengakibatkan gangguan terhadap kelestarian fungsi lingkungan karena kerusakan terumbu karang dan padang lamun di sepanjang pesisir Kabupaten Lampung Selatan.

\section{Ucapan Terima Kasih (Acknowledgement)}

Ucapan terima kasih kepada Lembaga Penelitian dan Pengabdian kepada Masyarakat (LPPM) Universitas Tarumanagara, Kepala BPBD Lampung Selatan, Kapolsek Kalianda dan berbagai pihak yang telah membantu.

\section{REFERENSI}

Admin. (2019, Maret 1). Dibiarkan, bangunan di GSP terus tumbuh https://www.lampost.co/berita-bangunan-hotel-di-jalan-wolter-monginsidi-didugalanggar-gsb.html

Hidayah, Z. \& Okol, S. S. (2018). Analisa perubahan penggunaan lahan wilayah pesisir selat Madura. Jurnal Ilmiah Rekayasa , 11(1), 20.

Jainah, Z. O. (2012). Penegakan hukum dalam masyarakat. Jurnal of Rural and Development, $\operatorname{III}(2), 167$.

Kalalo, F. P. (2016). Hukum lingkungan dan kebijakan pertanahan di wilayah Pesisir. PT Rajagrafindo Persada.

Prihatin, R. (2018). Masyarakat sadar bencana: Pembelajaran dari Karo, Banjarnegara, dan Jepang. Jurnal Masalah-Masalah Sosial, 9(2), 223.

Rejekiningsih, T. (2016). Asas fungsi sosial hak atas tanah pada negara hukum (Suatu tinjauan dari teori, yuridis, dan penerapannya di Indonesia). Jurnal Yustisia, 5(2), 301. 
Reki, N. D. (2018). Pembatasan kepemilikan dan penguasaan hak atas tanah dalam perspektif reforma agraria. Jurnal Hukum Magnum Opus, 1(1), 37.

Sanjiwani, P. K. (2016). Pengaturan hukum terhadap privatisasi sempadan pantai oleh pengusaha pantai di provinsi Bali. Analisis Pariwisata, 16(1), 3.

Sugandi, D. (2013). Pengelolaan sumber daya pantai. Jurnal Gea, 11(1), 55-56.

Umar, I., Widiatmaka, Pramudya, B, \& Barus, B. (2017). Prioritas pengembangan kawasan permukiman pada wilayah rawan banjir di kota Padang, Provinsi Sumatera Barat. Majalah Ilmiah Globe, 19(1), 83-84. 